\title{
REVIEW
}

\section{Alzheimer's disease and related neurodegenerative disorders: implication and counteracting of melatonin}

\author{
Miroslav Pohanka \\ Faculty of Military Health Sciences, University of Defense, Hradec Králové, Czech Republic \\ University Hospital Hradec Králové, Hradec Králové, Czech Republic
}

Received $21^{\text {st }}$ January 2011.

Revised $16^{\text {th }}$ February 2011.

Published online $7^{\text {th }}$ April 2011.

\begin{abstract}
Summary
Age related neurodegenerative disorders are becoming a serious public health problem. Alzheimer's disease (AD) is a progressive disease pathologically recognizable by deposition of neurofibrillary tangles and amyloid plaques. Oxidative stress probably plays a pivotal role in $\mathrm{AD}$, but despite expectations, antioxidants such as vitamin $\mathrm{E}$, vitamin $\mathrm{C}, \beta$ carotene, and flavonoids have failed as effective prophylaxis and/or treatment. Melatonin, a hormone controlling circadian rhythm, is a potent terminal antioxidant. In vitro tests and animal models have established that the application of melatonin could be beneficial for the amelioration of AD progression. Unfortunately, melatonin effects in human beings are not well understood and a lot of work has still to be done. The review summarizes the basic facts about melatonin and its prospects as a treatment for AD using its hormonal and antioxidant properties.
\end{abstract}

Key words:Alzheimer's disease; amyloid plaques; neurofibrillary tangles; tau; amyloid beta; oxidative stress; melatonin; antioxidant

\section{INTRODUCTION}

Alzheimer's disease (AD) is a neurodegenerative disorder with a not well understood aetiology. AD has become not only an ethical problem in public health care but it also an increasing item in care costs (Jonsson and Wimo 2009). Schumock (1998), for example, estimated the costs of $\mathrm{AD}$ treatment at the end of the 1990s, and calculated that the total cost per

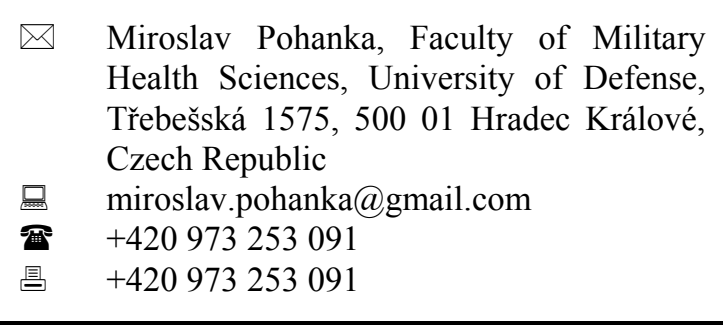

(C) Journal of Applied Biomedicine patient in the United States was 195, 000 USD, including nursing, drugs and family out-of-pocket expenses.

The aetiology of AD has not yet been established. It is recognized that amyloid beta and hyperphosphorylated tau protein (HPT) accumulates before the development of manifest AD (Leinonen et al. 2010), but the precise diagnosis of $A D$ is not simple. The Mini-Mental State Examination (MMSE) cognitive test, lasting approximately 45 minutes, is a simple option for fast diagnosis of dementias including AD (Wilson et al. 2002), because AD, as well as other dementias, can be accompanied by cognitive dysfunction, by apathy, aggression, irritability, and aberrant motor behavior; although anxiety and apathy seem to be more typical of AD than of the other dementias (Wetzels et al. 2010).

As will be discussed later, $\mathrm{AD}$ is closely associated with the impairment of the electron 
transport chain in mitochondria and the consequent oxidative stress (Pickrell et al. 2009). The application of an antioxidant is hypothesized as a promising treatment for AD (Flaherty et al. 2010). Melatonin is a potent antioxidant and endogenous hormone, and, when administered exogenously, it can act as a potent protective drug against oxidative stress related disorder and intoxications (Pohanka et al. 2011a). The present review considers the implication of oxidative stress in $\mathrm{AD}$, the potency of antioxidant treatment, gives a summary of the known facts and an estimation of promising ways to use melatonin as a drug for ameliorating $\mathrm{AD}$ pathogenesis.

\section{ALZHEIMER'S DISEASE MOLECULAR PATHOGENESIS}

Two major molecular mechanisms are related to AD pathology: amyloid beta deposition in the form of amyloid plaques and the creation of HPT forming neurofibrillary tangles. Amyloid beta is cleaved from the amyloid precursor protein (APP), but neither the physiological role of APP nor the mechanism of cleavage of the 42 amino acids long amyloid beta fragment (1-42) is fully understood. APP splitting is carried out by three secretases: $\alpha, \beta$, and $\gamma$. Fragments provided by $\alpha$-secretase are non-toxic and are not further modified by $\beta$ - and $\gamma$-secretases into potentially dangerous forms (Cole and Vassar 2007). Neurotoxic amyloid beta is created in two steps. In the first step, APP is cleaved by $\beta$-secretase (known also as an aspartic protease BACE 1 or memapsin 2). In the second step, $\gamma$-secretase containing the transmembrane protein presenilin finalizes the production of amyloid fragments (Coen and Annaert 2010). Amyloid beta peptides of different lengths can appear; typically 39-43 amino acids long (Kadlick et al. 2004). The most neurotoxic is the amyloid beta consisting of 42 amino acids (Jan et al. 2011a), which dominates the shorter amyloid peptides in $\mathrm{AD}$ patients (Kuperstein et al. 2010). Moreover, it is the most hydrophobic and fibrillogenic form of the cleaved fragments and it can simply form amyloid plaques in neurons (Murphy and LeVine 2010).

HPT is the second hallmark of damaged neurons in $\mathrm{AD}$ patients, and this pathogenesis is based on the deposit of neurofibrillar tangles inside the neurons. The origin of the tau is in the cytoskeleton where it stabilizes microtubules (Kao et al. 2010), becomes hyperphosphorylated due to not well understand mechanisms and can cause dementia diseases called tauopathy. Beside tauopathy in AD patients, tau is also implicated in the pathogenesis of Parkinson's disease (Lei et al. 2010). HPT contains phosphates bound via GSK-3 $\beta$ kinase into Ser199, Ser202, Ser 396, and Ser 404 (Cai et al. 2011).

Two major molecular changes relate to $\mathrm{AD}$. The link between neurofibrillary tangles and amyloid plaques is not well recognized, but the deposition of amyloid plaques probably starts before the formation of neurofibrillary tangles (Zheng et al. 2002). The whole pathogenesis is also tightly connected to the immune system and neuroinflammation probably plays a crucial role in the development of AD (Casoli et al. 2010). Although $A D$ is not specific to a particular region, the cerebral cortex and hippocampus are the most damaged regions (Raji et al. 2009).

\section{ALZHEIMER'S DISEASE AND OXIDATIVE STRESS}

There are several theories of senescence. Unfortunately, a definite answer to the question of why and how ageing appears has not been established. Two theories relating to $\mathrm{AD}$, seem to be the most plausible: firstly, ageing is the result of the chronic impact of reactive oxygen species, and secondly, resistance to oxidative stress is decreased due to some endogenous and/or exogenous effectors (Gilca et al. 2007). Oxidative insult probably triggers or augments AD pathology. On the other hand, the aetiology of many diseases and tissue damage may relate to oxidative stress and some authors suggest that reactive oxygen species are only a consequence and not a primary cause in these situations (Juránek and Bezek 2005).

Amyloid beta (1-42) toxic impact is not based only on the deposition of amyloid plaques but also on the adverse effects of redox reactions. Met 35 is responsible for the toxic properties of amyloid beta as it is associated with the generation of oxidative stress and the oxidative modification of macromolecules (Butterfield and Kanski 2002). Replacement or oxidation of Met 35 leads to the abolition or reduction of amyloid beta (1-42) toxicity (Clementi et al. 2006). The molecular mechanism of the pro-oxidant activities of amyloid beta (1-42) is not clear. It can reduce $\mathrm{Cu}^{\mathrm{II}+}$ to $\mathrm{Cu}^{\mathrm{I+}}$ and thus trigger a Fenton reaction (Boyd-Kimball et al. 2004), and it can also initiate cytochrome c release from the mitochondria and activation of apoptotic cascades. Substitution of Met 35 by norleucine abrogates the apoptotic cascade as proven on PC12 cell lines (Clementi and Misiti 2005). Cell lines affected by amyloid beta (1-42) and its fragments suffer from oxidative insult via the 
excessive production of nitric oxide, superoxide, and hydrogen peroxide as well as their reaction products such as peroxynitrite (Ill-Raga et al. 2010). Trans-4-hydroxy-2-hexenal is proven reactive product of the degradation of lipid membranes in the presence of amyloid beta (1-42) in neuronal cell lines or the brains (Butterfield and Lauderback 2002). The implication of amyloid beta (1-42) in oxidative stress is also confirmed by the fact that antioxidants such as vitamin E prevent amyloid beta (1-42) induced oxidative stress in model animals (Butterfield 2002).

The link between tau respective HPT and oxidative stress on the one hand and amyloid beta (1-42) and the formation of free radicals on the other is not clear. Though there is a need for further data about its role in the body the physiological role of tau is well researched and it has been proved that it is a compound able to fight wild oxidative and heat stress and to take part in the maintenance of homeostasis (Sultan et al. 2011). Brain tissue damage can cause hypoxia and thus generate oxidative stress (Guzy et al. 2005).

\section{CURRENT OPTIONS FOR ALZHEIMER'S DISEASE TREATMENT}

The pharmacotherapy of $\mathrm{AD}$ is based on the moderation of its manifestation, and calming of depressions, aggression etc. is a common process for the treatment of AD as well as the other dementias. Causative treatment of AD is not currently available. The common AD therapies mainly use inhibition of enzyme acetylcholinesterase (AChE), an enzyme participating in the termination of cholinergic neurotransmission. As the lack of the neurotransmitter acetylcholine is a negative process in the brain of $\mathrm{AD}$ patients, the AChE inhibitors can resolve acetylcholine deprivation. There are many known AChE inhibitors, but the prospects for AD treatment are conditioned by good penetration through the blood brain barrier. Inhibitors so far tested, such as the tetrahydroacridinium derivative tacrine and organophosphate metrifonate (trichlorfon) have adverse effects and clinical application has been terminated (Lopez-Arrieta and Schneider 2006, Alfirevic et al. 2007). The derivatives of tacrine have also been extensively investigated; however, they are not approved for therapeutic purposes (Pohanka et al. 2008, 2009, Korabecny et al. 2010). The AChE inhibitors currently available for AD treatment are donepezil, rivastigmine, and galantamine (Bonner and Peskind 2002). Another drug, huperzine, is being considered for clinical application; its variant huperzine $\mathrm{A}$ is especially preferred and acts not only as a non-competitive AChE inhibitor, but also as a non-competitive N-methyl-D-aspartate (NMDA) receptor antagonist (Zhang and $\mathrm{Hu}$ 2001). Some countries, such as China, provide huperzine as a regular drug (Desilets et al. 2009).

Memantine is the only available AD drug that acts in a way other than on the cholinergic system. It is a non-competitive antagonist of the NMDA receptor binding in the open channel form of the receptor (Potter 2010), which is a non selective ion channel playing an excitatory role. It is speculated that the receptor is involved in Alzheimer's disease aaetiology as it enhances the deposition of amyloid oligomers (Decker et al. 2010). Memantine is implicated in the reduction of amyloid beta (1-42) toxicity and is probably able to attenuate tau phosphorylation (Song et al. 2008). It can also protect neurons from calcium induced excitotoxicity (Lipton 2005). However, despite being well suited for the amelioration of some negative processes, it is not able either to resolve or to significantly slow down the progression of $\mathrm{AD}$ (Bassil et al. 2010). Past and current drugs for AD treatment are summarized in Table 1.

It has been proposed that other pathways can be affected in $\mathrm{AD}$ treatment. Inhibitors of $\gamma$ and $\beta$ secretases are promising compounds for clinical trials and growing interest can be expected in the development of novel compounds influencing secretases activity (He et al. 2010). As AD might be a consequence of oxidative insult and/or activation of the glial cells, the next effort will probably be aimed at resolving inflammatory processes and oxidative stress in the early stages of AD. From this point of view, melatonin can be a prospective compound in several pathways.

\section{ACTION OF ANTIOXIDANTS IN PATHOGENESIS OF ALZHEIMER'S DISEASE}

As the pathogenesis of $\mathrm{AD}$ is strongly related to the generation of oxygen and nitrogen reactive species, the application of low molecular weight antioxidants can be hypothesized as suitable for its counteraction. There is for example a proven protective effect of vitamin $E$ on neural cell culture exposed to 42 amino acids long amyloid beta (Yatin et al. 2000) and similar results have been noted in animal brains (Butterfield 2002). However, plausible confirmation of vitamin $\mathrm{E}$ or any other low molecular weight antioxidant protective or therapeutic effect is missing, despite extensive investigation. Devore et al. (2010) 
Pohanka: Alzheimer's disease and related neurodegenerative disorders

Table 1. Past and current drugs for Alzheimer's disease treatment.

\begin{tabular}{|c|c|c|c|}
\hline Drug & Systematic name & Mechanism of action & Fate \\
\hline Donepezil & $\begin{array}{l}(R S)-2-[(1-\text { benzyl-4-piperidyl) } \\
\text { methyl]-5,6-dimethoxy-2,3- } \\
\text { dihydroinden-1-one }\end{array}$ & $\begin{array}{l}\text { non-competitive (reversible) } \\
\text { AChE inhibitor }\end{array}$ & $\begin{array}{l}\text { Marketed under trade name } \\
\text { Aricept }\end{array}$ \\
\hline Rivastigmine & $\begin{array}{l}\text { (S)- } N \text {-Ethyl- } N \text {-methyl-3-[1- } \\
\text { (dimethylamino)ethyl]phenyl } \\
\text { carbamate }\end{array}$ & $\begin{array}{l}\text { pseudoirreverzible inhibition of } \\
\text { AChE and } \mathrm{BChE}\end{array}$ & $\begin{array}{l}\text { Available under trade name } \\
\text { Exelon }\end{array}$ \\
\hline Galantamine & $\begin{array}{l}(4 \mathrm{a} S, 6 R, 8 \mathrm{a} S)-5,6,9,10,11,12- \\
\text { hexahydro-3-methoxy-11- } \\
\text { methyl-4aH-[1]benzofuro[3a,3, } \\
\text { 2-ef] [2] benzazepin-6-ol }\end{array}$ & $\begin{array}{l}\text { competitive (reversible) } \\
\text { inhibition of } \mathrm{AChE}\end{array}$ & $\begin{array}{l}\text { Marketed under different trade } \\
\text { names such as Nivalin, } \\
\text { Razadyne, Reminyl... }\end{array}$ \\
\hline Huperzine A & $\begin{array}{l}(1 R, 9 S, 13 E)-1-\text { Amino-13- } \\
\text { ethylidene-11-methyl-6- } \\
\text { azatricyclo[7.3.1.02,7] trideca- } \\
\text { 2(7),3,10-trien-5-one }\end{array}$ & $\begin{array}{l}\text { non-competitive (reversible) } \\
\text { inhibitor of AChE and } \\
\text { non-competitive antagonist of } \\
\text { NMDA receptor }\end{array}$ & $\begin{array}{l}\text { Available in China; clinical } \\
\text { trials are not concluded }\end{array}$ \\
\hline Metrifonate & $\begin{array}{l}(R S)-2,2,2 \text {-trichloro-1- } \\
\text { dimethoxyphosphoryl-ethanol }\end{array}$ & $\begin{array}{l}\text { irreversible inhibitor of } \mathrm{AChE} \\
\text { and } \mathrm{BChE}\end{array}$ & $\begin{array}{l}\text { Withdrawn in AD treatment due } \\
\text { to adverse effects; available as } \\
\text { antihelmintic }\end{array}$ \\
\hline Tacrine & $\begin{array}{l}\text { 1,2,3,4-tetrahydroacridin-9- } \\
\text { amine }\end{array}$ & $\begin{array}{l}\text { non-competitive (reversible) } \\
\text { inhibitor of } \mathrm{AChE} \text { and } \mathrm{BChE}\end{array}$ & $\begin{array}{l}\text { Originally marketed as Cognex; } \\
\text { withdrawn due to adverse } \\
\text { effects, especially } \\
\text { hepatotoxicity }\end{array}$ \\
\hline Memantine & $\begin{array}{l}\text { 3,5-dimethyladamantan-1- } \\
\text { amine }\end{array}$ & $\begin{array}{l}\text { non-competitive antagonist of } \\
\text { NMDA receptor binding in the } \\
\text { open channel form of receptor }\end{array}$ & $\begin{array}{l}\text { Marketed under trade names } \\
\text { Abixa, Axura, Ebixa, Memox, } \\
\text { Namenda... }\end{array}$ \\
\hline
\end{tabular}

AChE - acetylcholinesterase; BChE - butyrylcholinesterase; NMDA - N-methyl-D-aspartic acid

disclaimed any plausible beneficial effect of vitamin $\mathrm{C}, \beta$ carotene, and flavonoids on the onset of $\mathrm{AD}$ pathogenesis. On the other hand, they found slight improvement in $\mathrm{AD}$ as an effect of vitamin $\mathrm{E}$ when administered in high doses. Most of the experimental work unfortunately, has failed to follow the composition of the vitamin E supplement. As seen from the work of Mangialasche et al. (2010), for example, the forms of vitamin $E$ have unequal efficacy. In vitamin E preparation, $\beta$ tocopherol had better efficacy than $\alpha$ tocopherol, $\alpha$ tocotrienol, and $\beta$ tocotrienol. Clinical trials proved a slight improvement in $\mathrm{AD}$ progression due to tocopherols, but the effect is not protective enough (Sano et al. 1997). Moreover, the low effect of the treatment process can be overbalanced by the adverse effects of antioxidants (Soni et al. 2010). It should also be emphasized that the previously noted improvements are only slight and the effects are hard to recognize. Co-application of vitamin $\mathrm{E}$ with $\mathrm{AD}$ drugs is, nevertheless, recommended in AD therapy (Doraiswamy 2002).

\section{MELATONIN BIOLOGICAL EFFECTS}

Melatonin (N-acetyl-5-methoxytryptamine) is a pineal gland hormone regulating time cyclicity in both animals and humans (Prendergast 2010). In the lower life forms, melatonin can act as an antioxidant protecting against the harmful impact of reactive oxygen and nitrogen species (Bustos-Obregon et al. 2005). In mammals, two G-coupled melatonin receptors are known: melatonin receptors $\mathrm{MT}_{1}$ and $\mathrm{MT}_{2}$. The receptors are responsible for circadian and 
seasonal responses, but the physiological implications are not fully recognized (Sugden et al. 2004). It has also become plausible that circadian regulation and hypnotic action are completely separate processes in the action of melatonin (Jan et al. 2011b). Beside the melatonin receptor, melatonin can act as an agonizing ligand of the retinoic acid receptor-related orphan receptor (ROR) $\alpha 1$ with the potential to control cell cycle and apoptosis-associated genes (Wiesenberg et al. 1995, Hill et al. 2009). The proven molecular impacts of melatonin are summarized in Fig. 1.

The role of melatonin as an endogenous antioxidant in humans and vertebrates is not clearly understood. Moreover, the lack of melatonin could be the reason for the higher incidence of Parkinson's disease and cancer in night workers and some other specific occupations (Schernhammer et al. 2006). In recent years, melatonin has been considered as a drug suitable for the suppression of the toxic impact of many compounds and ameliorating the pathogenesis of some diseases because of its fast suppression of oxidative stress (Korkmaz et al. 2009). Another impact - based on its expression of the IL-2 receptor - is not clearly understood. In animal models, it has been proved [by, for example, Mollace et al. (2005)] that melatonin mediates the inhibition of inducible nitric oxide synthase (iNOS), and cyclooxygenase 2 (COX2), and elevated levels of superoxide dismutase, glutathione reductase and glutathione peroxidase (as noted by, for example, Winiarska et al. 2006, Venkataraman et al. 2010). Melatonin could act as a very strong antioxidant. In comparison with the typical endogenous antioxidants, melatonin is an irreversible (also called 'suicidal') low molecular weight antioxidant. This means that the oxidized form of melatonin does not act as a pro-oxidative agent deteriorating redox status in other tissues, as is typical for the other antioxidants, and that it is not recovered into its initial molecule by the simple redox system. Moreover, the melatonin consumption products 6-hydroxymelatonin and $\mathrm{N}$-acetyl-N-formyl-5methoxykynurenamine, also act as antioxidants (Maharaj et al. 2007). The structures of melatonin and its degradation products are summarized in Fig. 2. The antioxidative effect of melatonin was recognized as suitable for its performance as a non-specific antioxidant after exposure to, for example, sulfur mustard (Pohanka et al. 2011a) or methamphetamine (Nopparat et al. 2010). On the other hand, there is some controversy in work on the impact of melatonin as the pro-oxidant activities of melatonin have also been recognized in human erythrocytal proteins (Dikmernoglu et al. 2008).

\section{MELATONIN POTENTIAL FOR ALZHEIMER'S DISEASE TREATMENT}

The prospects for melatonin as a treatment for $\mathrm{AD}$ are based on two independent pathways: a) scavenging of reactive oxygen and nitrogen species, and b) acting as a hormone or resolving sleep disturbance. Regarding the antioxidant action, oxidized melatonin does not act as a pro-oxidative agent, unlike the other endogenous low molecular weight antioxidants such as vitamin $\mathrm{C}$, vitamin $\mathrm{E}$, and glutathione (Tan et al. 2000). For this reason, melatonin could be found suitable in AD treatment in situations where the other antioxidants fail. On the other hand, rats with a melatonin enriched diet have been found to have significantly decreased levels of the antioxidant homocysteine (Murawska-Cialowicz et al. 2008). This points to a quite complex role for melatonin in organisms that could be negative as well as positive unless the application is supported by plausible experimentation. The prospects for melatonin in neuropathological processes in $\mathrm{AD}$ patients are underlined by the fact that the levels of melatonin can be low, as proved by Zhou et al. (2003) in an experiment on 121 subjects investigated postmortem. They recognized that individuals with a higher physiological level of melatonin had a reduced level of amyloid plaques and neurofibrillary tangles.

The role of melatonin as a potent molecule for the suppression of oxidative stress has been investigated by many teams. Experiments have shown that melatonin can ameliorate the overproduction of reactive oxygen species generated by complex I of the mitochondrial respiration chain by way of cardiolipin, an important part of the mitochondrial inner membrane protection (Petrosillo et al. 2008). Melatonin can keep the mitochondrial membrane fluidity as it protects from lipid peroxidation and it is speculated that mitochondrial membrane protection can slow down age related degeneration (García et al. 1997, 2010). However, this hypothesis needs to be confirmed and applied particularly to AD development in the early phases of pathogenesis. Recently, it was proved that the processes of senescence are altered in melatonin treated animals. Melatonin significantly modified not only oxidative stress related impairments, but also apoptotic processes and macroautophagic activities in senescence accelerated and slowed mice (Caballero et al. 2009). Alterations in NFאB, iNOS, TNF $\alpha$ and IL1 levels in a mice model are also involved in the biological effect of melatonin (Cuesta et al. 2010). Considering that AD, Parkinson's disease and some other neurodegenerative disorders are thought to be related to chronic inflammation (Gemma 2010), 


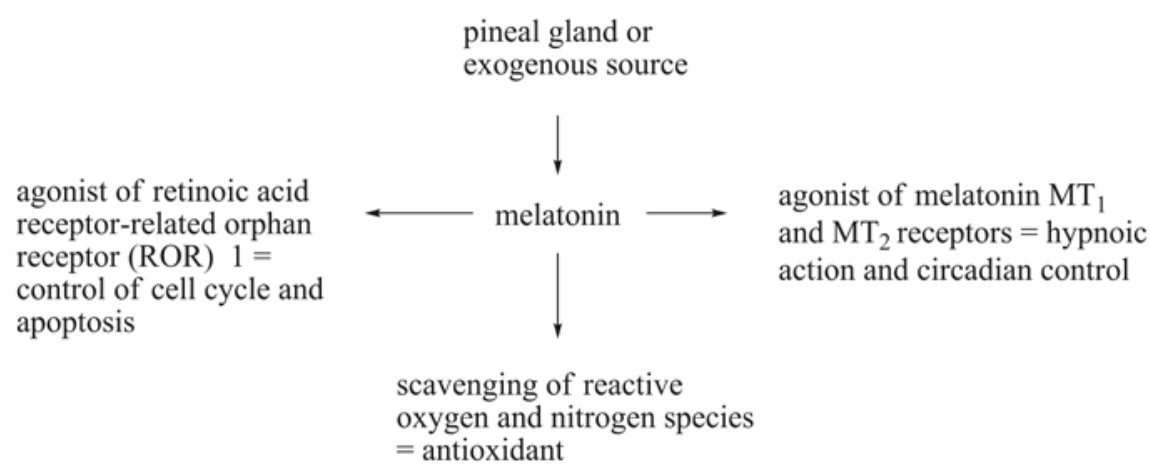

Fig. 1. Summarization of melatonin impact in mammal organism.<smiles>COc1ccc2[nH]cc(CCNC(C)=O)c2c1</smiles>

melatonin<smiles>COc1cc2c(CCNC(C)=O)c[nH]c2cc1O</smiles>

6-hydroxymelatonin<smiles>COc1ccc(NC=O)c(C(=O)CCNC(C)=O)c1</smiles>

$\mathrm{N}$-acetyl-N-formyl-5methoxykynurenamine

Fig. 2. Structures of melatonin and the most significant products of its oxidative degradation.

melatonin could be regarded as a compound for inflammation control (Wang and Wang 2006). On the other hand, if neurodegeneration is caused by neuroinflammation alone, the application of a standard steroidal or non-steroidal anti-inflammatory drug would be preferable. The role of the immune system in the nervous system is a complex one, and it can be detrimental when the autoimmune response for chronic inflammation is launched. Besides, the immune system function is necessary for protection against an invasion of pathogens (Gendelman 2002). It can be questioned whether the application of melatonin increases sensitivity to pathogens and enables pathogen invasion when the above mentioned suppression of innate immunity is considered. Unfortunately, this question has not yet been fully solved.

The link between circadian timing and the immune system has been hypothesized by many scientists (Berger 2008). The implication of melatonin in the modulation of apoptosis is similar to the effect of another antioxidant, epigallocatechin gallate. This green tea antioxidant was found to be able to influence extensively apoptosis in healthy mice exposed to sulfur mustard (Pohanka et al. 2011b).
The application of $10 \mathrm{mg} / \mathrm{kg}$ melatonin was found to be suitable for the suppression of some detrimental processes in the nervous system. It also triggered the up-regulation of the ROR $\alpha 1$ level. On the other hand, the application was without any implication in $\mathrm{MT}_{1}$ receptor presence in SAMP8 senescence accelerated mice and senescence slowed mice SAMR1 (Caballero et al. 2008). In this mouse model, the effects are corroborated for a long term application (five or ten months) that represents half and more of the life term given normal life expectancy. As reported by Gutierrez-Cuesta et al. (2007), the chronic administration of melatonin $10 \mathrm{mg} / \mathrm{kg}$ also had another significant effect in SAMP8 mice: reduced cell loss and oxidative damage of macromolecules. They found not only decreased hyperphosphorylation of tau, but also down-regulated activation of cdk5/p35 and its cleavage to cdk $5 / \mathrm{p} 25$; these point to a link between melatonin and reduced neurodegeneration on the level of its molecular control. On the other hand, it should be emphasized that the effect described followed quite a high dose of melatonin. Were the dose to be recalculated to the average human weight, it would be approximately two hundred times higher than the dose $3 \mathrm{mg}$ pro toto used for improvement of sleep quality (Nunes et al. 2008). 
Melatonin action as a hormone can be suitable for the treatment of sleep disturbances. AD patients have fragmented sleep, disturbing the normal sleep-wake circadian rhythm (Song et al. 2010); melatonin can correct this and improve physical as well as mental shape (David et al. 2010). It should also be noted that melatonin production decreases with age and that it is produced on a limited scale in $\mathrm{AD}$ patients so that the administration could substitute for the suppressed function of the pineal gland. This reduced production is considered a possible cause of the beneficial effect of melatonin pharmacological performance (Karasek and Reiter 2002, Karasek 2004). Although melatonin can influence the body in several ways and is a compound of considerable scientific interest, most of the results discussed were found in animal models or cell lines. Any clinically confirmed melatonin beneficial effects should be further investigated in a wide study as some of the preliminary results are encouraging: in particular its efficacy in the improvement of sleep in patients should be critically assessed. In considering any clinically proved efficacy of melatonin to treat insomnia in the elderly (Wade et al. 2010), it should again be noted that beneficial physical effects in humans are strongly influenced by sleep improvement alone. Also, Furio et al. (2007) have ascribed the effect of melatonin in a $\mathrm{AD}$ related study to circadian regulation rather than an antioxidant action. Similar conclusions were reached by Dowling et al. (2008). However, their study was carried out on a total of fifty subjects treated for ten weeks. The groups of 16, 17 and 17 specimens are quite small and smaller changes were not probably recognized. A systematic review carried out in 2005 provided similar results: there is insufficient evidence to support the effectiveness of melatonin in the treatment of the cognitive and non-cognitive sequences of dementia (Jansen et al. 2006). More responsible data can be observed when melatonin is administered to people 55 years and over together with the investigation of the occurrence of new $\mathrm{AD}$ cases and the further progression of $\mathrm{AD}$. Unfortunately, such clinical trials have not yet taken place.

\section{CONCLUSIONS AND EXPECTATIONS FOR THE FUTURE}

Despite the significant effect of melatonin on neuro-degeneration in experimental models, its potency in protecting neurons from aggravation is neither fully understood nor plausibly recognized in clinical studies. For the next decades, experiments and trials on human beings can be expected. The pertinent experiments based on application of melatonin to human beings suffering from neurodegenerative disorders are now simplified by the fact that melatonin has been approved as a food supplement and drug for insomnia by the (U.S.) Food and Drug Administration agency and there are only minimal or no adverse effects (Taylor and Weiss 2009). The favourability of melatonin for treatment is emphasized by two facts: melatonin is quite cheap and simple to synthesis as a derivative of tryptophan with an intact indol core (Estevao et al. 2010) and melatonin is maintained in the body for a long time. Some authors [e.g. Mistraletti et al. (2010)] have referred to the keeping of the pharmacological level in serum for 10 hours following enteral administration when the pharmacological level is reached after approximately 5 minutes with serum peak after 16 minutes.<smiles>[Y]C(=C(CCc1c[nH]c2ccc([R7])cc12)NCCc1c[nH]c2ccccc12)C(C)(C)CC([2H])(C)Nc1c2c(nc3cccc([R])c13)CCCC2</smiles>

Fig. 3. Derivatives composed from tacrine and melatonin prepared by Fernandez-Bachiller et al. (2009). $\mathrm{R}_{1}=-\mathrm{H},-\mathrm{OCH}_{3} ; \mathrm{R}_{2}=-\mathrm{H},-\mathrm{Cl}$, bis $\mathrm{Cl}(6,8$ position $) ; \mathrm{X}=\mathrm{O}$ or $\mathrm{S}$; $\mathrm{n}=4,5,6$, or 7 .

Recent investigations have proposed that the deposition of amyloid plaque may be accelerated or even triggered by the interaction of amyloid beta (1-42) with the anionic subsite of AChE (Castro and Martinez 2006). Considering the stress insult necessary for amyloid beta deposition and amyloid plaque, the conjugates of the $\mathrm{AChE}$ inhibitor with antioxidant are promising drugs of the next generation. Tacrine-melatonin heterodimers have been extensively investigated in addition to the other compounds (Tumiatti et al. 2010). We can speculate how prepared compounds can be effective not only for the amelioration of $\mathrm{AD}$ symptomatic 
manifestation but also because of their ability to slow down the pathogenesis progression. For example Fernandez-Bachiller et al. (2009) prepared derivatives of tacrine linked to melatonin via amine of tacrine and $\mathrm{N}$-acetyl of melatonin. The prepared derivatives (see common structure in Fig. 3) kept good inhibitory potency to AChE as well as antioxidant ability in vitro. Especially the chloro and bischloro derivates of tacrine linked to melatonin by six carbon long chains, had significantly higher selectivity to $\mathrm{AChE}$ compared to butyrylcholinesterase (BChE) retaining antioxidant ability and strong inhibitory potency to human AChE. We can expect next an effort to prepare new melatonin derivatives and confirmation of their effects on animal models in the short or medium term range. Unfortunately, the pertinent performance of these novel derivatives is limited, as the biological effect of melatonin complex on neurodegeneration is not fully understood.

\section{ACKNOWLEDGEMENT}

The Czech Science Foundation is gratefully acknowledged for the project No. P303/11/1907.

\section{REFERENCES}

Alfirevic A, Mills T, Carr D, Barratt BJ, Jawaid A, Sherwood J, Smith JC, Tugwood J, Hartkoorn R, Owen A, Park KB, Pirmohamed M. Tacrine-induced liver damage: an analysis of 19 candidate genes. Pharmacogenet Genomics. 17: 1091-1100, 2007.

Bassil N, Thaipisuttikul P, Grossberg GT. Memantine ER, a one-daily formulation for the treatment of Alzheimer's disease. Expert Opin Pharmacother. 11: 1765-1771, 2010.

Berger J. A two-clock model of circadian timing in the immune system of mammals. Pathol Biol (Paris). 56: 286-291, 2008.

Bonner LT, Peskind ER. Pharmacologic treatments of dementia. Med Clin North Am. 86: 657-674, 2002.

Boyd-Kimball D, Sultana R, Mohammad-Abdul H, Butterfield DA. Rodent A $\beta(1-42)$ exhibits oxidative stress properties similar to those of human $A \beta(1-42)$ : Implication for proposed mechanisms of toxicity. J Alzheimers Dis. 6: 515-525, 2004.

Bustos-Obregon E, Gonzalez JR, Espinoza O. Melatonin as protective agent for the cytotoxic effects of diazinon in the spermatogenesis in the earthworm Eisenia foetida. Ital J Anat Embryol. 110: 159-165, 2005.

Butterfield DA. Amyloid beta-peptide (1-42)-induced oxidative stress and neurotoxicity: implications for neurodegeneration in Alzheimer's disease brain. A review. Free Radic Res. 36: 1307-1313, 2002.

Butterfield DA, Kanski J. Methionine residue 35 is critical for the oxidative stress and neurotoxic properties of Alzeheimer's amyloid beta-peptide 1-42. Peptides. 23: 1299-1309, 2002.

Butterfiedl DA, Lauderback CM. Lipid peroxidation an protein oxidation in Alzheimer's disease brain: potential causes and consequences involving amyloid beta-peptide-associated free radical oxidative stress. Free Radic Biol Med. 32: 1050-1060, 2002.

Caballero B, Vega-Naredo I, Sierra V, Huidobro-Fernandez C, Soria-Valles C, De Gonzalo-Calvo D, Tolivia D, Gutierrez-Cuesta J, Pallas M, Camins A, Rodriguez-Colunga MJ, Coto-Montes A. Favorable effects of a prolonged treatment with melatonin on the level of oxidative damage and neurodegeneration in sensescence-accelerated mice. J Pineal Res. 45: 302-311, 2008.

Caballero B, Vega-Naredo I, Sierra V, Huidobro-Fernandez C, Sorie-Valles C, De Gonzalo-Calvo D, Tolivia D, Pallas M, Camins A, Rodriguez-Colunga MJ, Coto-Montes A. Melatonin alters cell death processes in response to age-related oxidative stress in the brain of senescence-accelerated mice. J Pineal Res. 46: 106-114, 2009.

Cai T, Che H, Yao T, Chen Y, Huang C, Zhang W, Du K, Zhang J, Cao Y, Chen J, Luo W. Manganese induces tau hyperphosphorylation through the activation of ERK MAPK pathway in PC12 cells. Toxicol Sci. 119: 169-177, 2011.

Casoli T, Di Stefano G, Balietti M, Solazzi M, Giorgetti B, Fattoretti P. Peripheral inflammatory biomarkers of Alzheimer's disease: the role of platelets. Biogerontology. 11: 627-633, 2010.

Castro A, Martinez A. Targeting beta-amyloid pathogenesis through acetylcholinesterase inhibitors. Curr Pharm Des. 12: 4377-4387, 2006.

Clementi ME, Misiti F. Substitution of methionine 35 inhibits apoptotic effects of $A \beta(31-35)$ and $A \beta$ (25-35) fragments of amyloid beta protein in PC12 cells. Med Sci Monit. 11: BR381-385, 2005.

Clementi ME, Pezzotti M, Orsini F, Sampaolese B, Mezzogori D, Grassi C, Giardina B, Misiti F. Alzheimer's amyloid beta-peptide (1-42) induces 
cell death in human neuroblastoma via bax/bcl-2 ratio increase: an intriguing role for methionine 35. Biochem Biophys Res Commun. 342: 206-213, 2006.

Coen K, Annaert W. Presenilins: how much more than $\gamma$-secretase?! Biochem Soc Trans. 38: 1474-1478, 2010.

Cole SL, Vassar R. The Alzheimer's disease $\beta$-secretase enzyme, BACE I. Mol Neurodeg. 2: 22, 2007.

Cuesta S, Kireev R, Forman K, García C, Escames G, Ariznavarreta C, Vara E, Tresguerres JAF. Melatonin improves inflammation processes in liver of senescence-accelerated prone male mice (SAMP8). Exp Gerontol. 45: 950-956, 2010.

David R, Zeitzer J, Friedman L, Noda A, O'Hara R, Robert P, Yesavage JA. Non-pharmacologic management of sleep disturbance in Alzheimer's disease. J Nutr Health Aging. 14: 203-206, 2010.

Decker H, Jurgensen S, Adrover MF, Brito-Moreira J, Bomfim TR, Klein WL, Epstain AL, De Felice FG, Jerusalinsky D, Ferreira ST. N-methyl-Daspartate receptors are required for synaptic targeting of Alzheimer's toxic amyloid- $\beta$ peptide oligomers. J Neurochem. 115: 1520-1529, 2010.

Desilets AR, Gickas JJ, Dunican KC. Role of huperzine A in the treatment of Alzheimer's disease. Ann Pharmacother. 43: 514-518, 2009.

Devore EE, Grodstein F, van Rooij FJ, Hofman A, Stampfer MJ, Witteman JC, Breteler MM. Dietary antioxidants and long-term risk of dementia. Arch Neurol. 67: 819-825, 2010.

Dikmernoglu N, Ileri E, Seringec N, Ercil D. Melatonin prevents lipid peroxidation in human erythrocytes but augments deterioration of deformability after in vitro oxidative stress. Clin Hemorheol Microcirc. 40: 235-242, 2008.

Doraiswamy PM. Non-cholinergic strategies for treating and preventing Alzheimer's disease. CNS Drugs. 16: 811-824, 2002.

Dowling GA, Burr RL, Van Someren EJ, Hubbard EM, Luxenberg JS, Mastick J, Cooper BA. Melatonin and bright-light treatment for rest-activity disruption in institutionalized patients with Alzheimer's disease. J Am Geriatr Soc. 56: 239-246, 2008.

Estevao MS, Carvalho LC, Ribeiro D, Couto D, Freitas M, Gomes A, Ferreira LM, Fernandes E, Marques MMB. Antioxidant activity of unexplored indole derivatives: synthesis and screening. Eur J Med Chem. 45: 4869-4878, 2010.

Fernández-Bachiller MI, Pérez C, Campillo NE, Páez JA, González-Muñoz GC, Usán P, GarcíaPalomero E, López MG, Villaroya M, García AG,
Martínez A, Rodríguez-Franco MI. Tacrinemelatonin hybrids as multifunctional agents for Alzheimer's disease, with cholinergic, antioxidant, and neuroprotective properties. Chem Med Chem. 4: 828-841, 2009.

Flaherty DP, Kiyota T, Dong Y, Ikezu T, Vennerstrom JL. Phenolic bis-styrylbenzenes as $\beta$-amyloid binding ligands and free radicals scavengers. J Med Chem. 53: 7992-7999, 2010.

Furio AM, Brusco LI, Cardinali DP. Possible therapeutic value of melatonin in mild cognitive impairement: a retrospective study. J Pineal Res. 43: 404-409, 2007.

García JJ, Reiter RJ, Guerrero JM, Escames G, Yu BP, Ho CS, Muñoz-Hoyos A. Melatonin prevents changes in microsomal membrane fluidity during induced lipid peroxidation. FEBS Lett. 408: 297-300, 1997.

García JJ, Piñol-Ripoll G, Martínez-Ballarin E, Fuentes-Broto L, Miana-Mena FJ, Venegas C, Caballero B, Escames G, Coto-Montes A, Acuña-Castroviejo D. Melatonin reduces membrane rigidity and oxidative damage in the brain of SAMP(8) mice. Neurobiol Aging, 2010 In press, doi: 10.1016/j.neurobiolaging.2009.12. 013.

Gemma C. Neuroimmunomodulation and aging. Aging Dis. 1: 169-172, 2010.

Gendelman HE. Neural immunity: friend or foe? J Neurovirol. 8: 474-479, 2002.

Gilca M, Stoian I, Atanasiu V, Virgolici B. The oxidative hypothesis of senescence. J Postgrad Med. 53: 207-213, 2007.

Gutierrez-Cuesta J, Sureda FX, Romeu M, Canudas AM, Caballero B, Coto-Montes A, Camins A, Pallas M. Chronic administration of melatonin reduces cerebral injury biomarkers in SAMP8. J Pineal Res. 42: 394-402, 2007.

Guzy RD, Hoyos B, Robin E, Chen H, Liu L, Mansfield KD, Simon MC, Hammerling U, Schumacker PT. Mitochondrial complex III is required for hypoxia-induced ROS production and cellular oxygen sensing. Cell Metab. 1: 401-408, 2005.

He G, Luo W, Li P, Remmers C, Netzer WJ, Hendrick J, Bettayeb K, Flajolet M, Gorelick F, Wennogle LP, Greengard P. Gamma-secretase activating preotein is a therapeutic target for Alzheimer's disease. Nature. 467: 95-98, 2010.

Hill SM, Frasch T, Xiang S, Yuan L, Duplessis T, Mao L. Molecular mechanisms of melatonin anticancer effects. Integr Cancer Ther. 8: 337-346, 2009.

Ill-Raga G, Ramos-Fernandez E, Guix FX, Tajex M, Bosch-Morato M, Palomer E, Godoy J, Belmar S, 
Cerpa W, Simpkins JW, Inestrosa And NC, Munoz FJ. Amyloid- $\beta$ peptide fibrils induce nitro-oxidative stress in neuronal cells. $\mathrm{J}$ Alzheimers Dis. 22: 641-652, 2010.

Jan A, Adolfosson O, Allaman I, Buccarello AL, Magistretti PJ, Pfeifer A, Muhs A, Lashuel HA. $\mathrm{A}(\beta) 42$ neurotoxicity is mediated by ongoing nucleated polymerization process rather than by discrete $A(\beta) 42$ species. J Biol Chem. 286: 8585-8596, 2011a.

Jan JE, Reiter RJ, Wong PK, Bax MC, Ribary U, Wasdell MB. Melatonin has membrane receptroindependent hypnotic action on neurons: an hypothesis. J Pineal Res. 50: 233-240, 2011 b.

Jansen SL, Forbes DA, Morgan DG. Melatonin for cognitive impairment. Cochrane Database Syst Rev. CD003802.pub3, 2006.

Jonsson L, Wimo A. The cost of dementia in Europe: a review of the evidence, and methodological considerations. Pharmacoeconomics. 27: 391-403, 2009.

Juránek I, Bezek S. Controversy of free radical hypothesis: reactive oxygen species - cause or consequence of tissue injury? Gen Physiol Biophys. 24: 263-278, 2005.

Kadlcik V, Sicard-Roselli C, Mattioli TA, Kodicek M, Houée-Levin C. One-electron oxidation of beta-amyloid peptide: sequence modulation of reactivity. Free Radic Biol Med. 37: 881-891, 2004.

Kao PF, Davis DA, BAnigan MG, Vanderburg CR, Seshadri S, Delalle I. Modulators of cytoskeletal rearganization in CA1 hippocampal neurons show increased expression in patients at mid-stage Alzheimer's disease. PLoS One. 5:e13337, 2010.

Karasek M. Melatonin, human aging, and age-related diseases. Exp Gerontol. 39: 1723-1729, 2004.

Karasek M, Reiter RJ. Melatonin and aging. Neuro Endocrinol Lett. 1: 14-16, 2002.

Korabecny J, Musilek K, Holas O, Binder J, Zemek F, Marek J, Pohanka M, Opletalova V, Dohnal V, Kuca K. Synthesis and in vitro evaluation of $\mathrm{N}$-alkyl-7-methoxytacrine hydrochlorides as potential cholinesterase inhibitors in Alzheimer disease. Bioorg Med Chem Lett. 20: 6093-6095, 2010.

Korkmaz A, Reiter RJ, Topal T, Manchester LC, Oter S, Tan DX. Melatonin: an established antioxidant worthy of use in clinical trials. Mol Med. 15: 43-50, 2009.

Kuperstein I, Broersen K, Benilova I, Rozenski J, Jonckheere W, Debulpaep M, Vandersteen A, Sagers-Nolten I, Van Der Werf K, Subramaniam V, Braeken D, Callewaert G et al. Neurotoxicity of Alzheimer's disease $A \beta$ peptides is induced by small changes in the $A(\beta) 42$ to $A(\beta) 40$ ratio. EMBO J. 29: 3408-3420, 2010.

Lei P, Ayton S, Finkelstein DI, Adlard PA, Masters CL, Bush AI. Tau protein: relevance to Parkinson's disease. Int J Biochem Cell Biol. 42: 1775-1778, 2010.

Leinonen V, Koivisto AM, Savolainen S, Rummukainen J, Tamminen JN, Tillgren $\mathrm{T}$, VAinikka S, Pyykko OT, Molsa J, Fraunberg M, Pirtilla T, Jaaskelainen JE et al. Amyloid and tau proteins in cortical brain biopsy and Alzheimer's disease. Ann Neurol. 68: 446-453, 2010.

Lipton SA. The molecular basis of memantine action in Alzheimer's disease and other neurologic disorders: low affinity, uncompetitive antagonism. Curr Alzheimer Res. 2: 155-165, 2005.

Lopez-Arrieta JM, Schneider L. Metrifonate for Alzheimer's disease. Cochrane Database Syst Rev CD003155, 2006.

Maharaj DS, Glass BD, Daya S. Melatonin: new places in therapy. Biosci Rep. 27: 299-320, 2007.

Mangialasche F, Kivipelto M, Mecocci P, Rizzuto D, Palmer K, Winblad B, Fratiglioni L. High plasma levels of vitamin $\mathrm{E}$ forms and reduced Alzheimer's disease risk in advanced age. J Alzheimers Dis. 20: 1029-1037, 2010.

Mistralleti G, Sabbatini G, Taverna M, Figini MA, Umbrello M, Magni P, Ruscica M, Dozio E, Esposti R, DeMartini G, Fraschini F, Rezzani R et al. Pharmacokinetics of orally administered melatonin in critically ill patients. J Pineal Res. 48: 142-147, 2010.

Mollace V, Muscoli C, Masini E, Cuzzocrea S, Salvemini D. Modulation of prostaglandin biosynthesis by nitric oxide and nitric oxide donors. Pharmacol Rev. 57: 217-252, 2005.

Murawska-Cialowicz E, Januszewska L, ZuwalaJagiello J, Milczarska J, Zawadzki M, Paprocka-Borowicz M, Wierbicka-Damska I. Melatonin decreases homocysteine level in blood of rats. J Physiol Pharmacol. 59: 717-729, 2008.

Murphy MP, LeVine H. Alzheimer's disease and the $\beta$-amyloid peptide. J Alzheimers Dis. 19: 311-323, 2010.

Nopparat C, Porter JE, Ebadi M, Govitrapong P. The mechanism for the neuroprotective effect of melatonin against methamphetamine-induced autophagy. J Pineal Res. 49: 382-389, 2010.

Nunes DM, Mota RMS, Machado MO, Pereira EDB, de Bruin VMS, de Bruin PFC. Effect of melatonin administration on subjective sleep quality in chronic obstructive pulmonary disease. Braz J Med Biol Res. 41: 926-931, 2008.

Petrosillo G, Fattoretti P, Matera M, Ruggiero FM, 
Bertoni-Freddari C, Paradies G. Melatonin prevents age-related mitochondrial dysfunction in rat brain via cardiolipin protection. Rejuvenation Res. 11: 935-943, 2008.

Pickrell AM, Fukui H, Moraes CT. The role of cytochrome $\mathrm{c}$ oxidase deficiency in ROS and amyloid plaque formation. J Bioenerg Biomembr. 41: 453-456, 2009.

Pohanka M, Kuca K, Kassa J. New performance of biosensor technology for Alzheimer's disease drugs: in vitro comparison of tacrine and 7-methoxytacrine. Neuroendocrinol Lett. 29: 755-758, 2008.

Pohanka M, Musilek K, Kuca K. Progress of biosensors based on cholinesterase inhibition. Curr Med Chem. 16: 1790-1798, 2009.

Pohanka M, Sobotka J, Jilkova M, Stetina R. Oxidative stress after sulfur mustard intoxication and its reduction by melatonin: efficacy of antioxidant therapy during serious intoxication. Drug Chem Toxicol. 34: 85-91, 2011 a.

Pohanka M, Sobotka J, Stetina R. Sulfur mustard induced oxidative stress and its alteration by epigallocatechin gallate. Toxicol Lett., 2011b-In press, doi: 10.1016/j.toxlet.2010.12.011.

Potter PE. Investigational medications for treatment of patients with Alzheimer disease. J Am Osteopath Assoc. 110: S27-S36, 2010.

Prendergast BJ. MT1 melatonin receptors mediate somatic, behavioral, and reproductive neuroendocrine responses to photoperiod and melatonin in Siberian hamsters (Phodopus sungorus). Endocrinology. 15: 714-721, 2010.

Raji CA, Lopez OL, Kuller LH, Carmichael OT, Becker JT. Age, Alzheimer disease, and brain structure. Neurology. 73: 1899-1905, 2009.

Sano M, Enesto C, Thomas RG, Klauber MR, Schafer K, Grundman M, Woodbury P, Growdon J, Cotman CW, Pfeiffer E, Schneider LS, Thal LJ. A controlled trial of selegiline alpha-tocopherol, or both as treatment for Alzheimer's disease. The Alzheimer's Disease Cooperative Study. N Engl J Med. 336: 1216-1222, 1997.

Schernhammer E, Chen H, Ritz B. Circulating melatonin levels: possible link between Parkinson's disease and cancer risk? Cancer Causes Control. 17: 577-582, 2006.

Schumock GT. Economic consideration in the treatment and management of Alzheimer's disease. Am J Health Syst Pharm. 55: S17-S21, 1998.

Song MS, Rauw G, Baker GB, Kar S. Memantine protects rat cortical cultured neurons against beta-amyloid-induced toxicity by attenuating tau phosphorylation. Eur J Neurosci. 28: 1989-2002,
2008.

Song Y, Dowling GA, Wallhagen MI, Lee KA, Strawbridge WJ. Sleep in older aults with Alzheimer's disease. J Neurosci Nurs. 42: 190-198, 2010.

Soni MG, Thurmond TS, Miller ER, Spriggs T, Bendich A, Omaye ST. Safety of vitamins and minerals: controversies and perspective. Toxicol Sci. 118: 348-355, 2010.

Sugden D, Davidson K, Hough KA, Teh MT. Melatonin, melatonin receptors and melanophores: a moving story. Pigment Cell Res. 17: 454-460, 2004.

Sultan A, Nesslany F, Violet M, Bégard S, Loyens A, Talahari S, Mansuroglu Z, Marzin D, Sergeant N, Humez S, Colin M, Bonnefoy E, Buée L, Galas MC. Nuclear tau: a key player in neuronal DNA protection. J Biol Chem. 286: 4566-4575, 2011.

Tan DX, Manchester LC, Reiter RJ, Qi WB, Karbownik M, Calvo JR. Significance of melatonin in antioxidative defense system: reactions and products. Biol Signals Recept. 9: 137-159, 2000.

Taylor SR, Weiss JS. Review of insomnia pharmacotherapy options for the elderly: implications for managed care. Popul Health Manag. 12: 317-323, 2009.

Tumiatti V, Minarini A, Bolognesi ML, Milelli A, Rosini M, Melchiorre C. Tacrine derivatives and Alzheimer's disease. Curr Med Chem. 17: 1825-1838, 2010.

Venkataraman P, Selvakumar K, Krishnamoorthy G, Muthusami S, Rameshkumar R, Prakash S, Arunakaran J. Effect of melatonin on PCB (Aroclor 1254) induced neuronal damage and changes in $\mathrm{Cu} / \mathrm{Zn}$ superoxide dismutase and glutathione peroxidase-4 mRNA expression in cerebral cortes, cerebellum and hippocampus of adult rats. Neurosci Res. 66: 189-197, 2010.

Wade AG, Ford I, Crawford G, McConnachie A, Nir T, Laudon M, Zisapel N. Nightly treatment of primary insomnia with prolonged release melatonin for 6 months: a randomized placebo controlled trial on age and endogenous melatonin as predictors of efficacy and safety. BMC Med. 8: 51, 2010.

Wang JZ, Wang ZF. Role of melatonin in Alzheimer-like neurodegeneration. Acta Pharmacol Sin. 27: 41-49, 2006.

Wetzels RB, Zuidema SU, de Jonghe JF, Verhey FR, Koopmans RT. Course of neuropsychiatric symptoms in residents with dementia in nursing homes over 2-year period. Am J Geriatr Psychiatry. 18: 1054-1065, 2010.

Wiesenberg I, Missbach M, Kahlen JP, Schrader M, 
Carlberg C. Transcriptional activation of the nuclear receptor RZR $\alpha$ by the pineal gland hormone melatonin and identification of CGP 52608 as a synthetic ligand. Nucleic Acids Res. 23: 327-333, 1995.

Wilson RS, Mendes De Leon CF, Barnes LL, Schneider JA, Evans DA, Bennett DA. Participation in cognitively stimulating activities and risk of incident Alzheimer disease. JAMA. 287: 742-748, 2002.

Winiarska K, Fraczyk T, Malinska D, Drozak J, Bryla J. Melatonin attenuates diabetes-induced oxidative stress in rabbits. J Pineal Res. 40: 168-176, 2006.

Yatin SM, Varadarajan S, Butterfield DA. Vitamin E prevents Alzheimer's amyloid beta-peptide (1-42) induced neuronal protein oxidation and reactive oxygen species production. J Alzheimers Dis. 2: 123-131, 2000.

Zhang JM, Hu GY. Huperzine A, a nootropic alkaloid, inhibits N-methyl-D-aspartate-induced current in rat dissociated hippocampal neurons. Neuroscience. 105: 663-669, 2001.

Zheng WH, Bastianetto S, Menniken F, Ma W, Kar S. Amyloid beta peptide induces tau phosphorylation and loss of cholinergic neurons in rat primary septal cultures. Neuroscience. 115: 201-211, 2002.

Zhou JN, Liu RY, Kamphorst W, Hofman MA, Swaab DF. Early neuropathological Alzheimer's changes in aged individuals are accompanied by decreased cerebrospinal fluid melatonin levels. J Pineal Res. 35: 125-130, 2003. 